\title{
Uji Tumbuh Kapang Aspergillus niger pada Beberapa Media Bahan Pangan Asal Sulawesi Utara
}

\author{
Meiske Naomi Mamuaja ${ }^{a^{*}}$, Dokri Gumolung ${ }^{a}$ \\ a Kimia, FMIPA, Universitas Negeri Manado, Tondano, 95618, Indonesia
}

\begin{tabular}{l} 
IN F O A R T I K E L \\
\hline Diterima 4 September 2018 \\
Disetujui 25 September 2018 \\
\\
\hline Key word: \\
Functional food, \\
Aspergillus niger, \\
Fructooligossaccharide (FOS), \\
Prebiotic \\
\hline Kata kunci: \\
Pangan fungsional \\
Aspergillus niger, \\
Fruktooligosakarida, \\
Prebiotik \\
\hline
\end{tabular}

\begin{abstract}
A B STR A C T
The development of functional food today mainly focuses on founding food that rich in nutrition and also provide health benefit for human consumption. At this point the combination of prebiotic and probiotic food that refer to food with health benefit to help digestible function become increasing. This research was done by literature study and laboratory experiment with 5 medium and 4 replications in order to found the possibility to produce fructooligosaccharide from Aspergillus niger fermentation in some typical foodstuffs from North Sulawesi i.e pisang goroho (Musa acuminate), sweet potato (Ipomeae batatas), coconut water, and palm sugar. Statistical analysis of the results shown that the Aspergillus niger tend to grow in 4 of 5 medium which indicate the possibility of fructooligosaccharide in those medium. Further studies are needed in order to know the production of fructooligossaccharide based on its medium.
\end{abstract}

\section{A B STRAK}

Pengembangan pangan fungsional saat ini berfokus pada makanan yang kaya nutrisi dan juga memberikan manfaat kesehatan bagi konsumsi manusia. Pada titik ini kombinasi makanan prebiotik dan probiotik yang mengacu pada makanan dengan manfaat kesehatan untuk membantu meningkatkan fungsi pencernaan. Penelitian ini dilakukan dengan studi pustaka dan percobaan laboratorium dengan 5 media dan 4 pengulangan untuk menemukan kemungkinan untuk menghasilkan fruktooligosakarida dari fermentasi Aspergillus niger di beberapa bahan makanan khas dari Sulawesi Utara yaitu pisang goroho (Musa acuminate), ubi jalar (Ipomeae batatas), air kelapa, dan gula aren. Analisis statistik dari hasil menunjukkan bahwa Aspergillus niger cenderung tumbuh di 4 dari 5 medium yang mengindikasikan kemungkinan fructooligosaccharide pada medium tersebut. Penelitian lebih lanjut diperlukan untuk mengetahui produksi fructooligossaccharide berdasarkan medianya.

*e-mail:

m315nm@gmail.com

*Telp:

085256466794

\section{Pendahuluan}

Pangan fungsional didefinisikan sebagai pangan yang mampu memberikan efek menguntungkan pada satu atau lebih fungsi dalam tubuh, di luar efek nutrisi biasa, dengan cara yang relevan dalam meningkatkan status kesehatan dan kehidupan dan/atau mengurangi resiko penyakit. Saat ini, penelitian pangan fungsional berpusat pada pengembangan penelitian berbasis kesehatan, nutrisi dan pengolahan pangan.

Perhatian utama saat ini adalah konsep probiotik dan prebiotik sebagai pangan fungsional [1]. Probiotik didefinisikan sebagai pangan yang berisi kultur mikroorganisme, baik sebagai hasil dari fermentasi atau yang secara sengaja ditambahkan dengan tujuan untuk memberikan keuntungan bagi inangnya seiring dengan meningkatnya keseimbangan mikrobia intestinal [2]. Selanjutnya prebiotik didefinisikan sebagai komponen yang tidak dapat dicerna manusia dengan pencernaan biasa manusia dan memerlukan kerja enzimatik mikroorganisme usus halus dan pada gilirannya memberikan efek menguntungkan bagi kesehatan. Kombinasi antara probiotik dan prebiotik yang dikenal sebagai pangan simbiosis diketahui mampu memberikan efek positif yang signifikan bagi kesehatan manusia[3].

Salah satu jenis prebiotik yang mempunyai fungsi kesehatan yang sangat baik 
dalam tubuh sekaligus sebagai pengganti gula adalah fruktooligosakarida (FOS). Bagi dunia pangan, FOS memiliki keuntungan karena bisa diproduksi secara massal dan rasa manisnya yang tidak berbeda jauh dengan sukrosa yang biasa digunakan sebagai gula meja tradisional [4]. Selain itu FOS telah mendapatkan sertifikat GRAS (generally recognized as safe) dari Food and Drug Administration Amerika Serikat (FDA US). Menurut Maiorano harga per kilogram gula FOS mencapai USD 200 [5]. Flamm melaporkan rata-rata konsumsi FOS per hari yang mencapai 1-4 g pada orang Amerika dan 3 - 11 g pada orang Eropa [3]. Selain terdapat dalam jumlah yang sangat kecil pada bahan pangan, FOS dapat diproduksi melalui proses fermentasi oleh beberapa mikroorganisme pangan. Sampai saat ini kebutuhan FOS Indonesia masih sepenuhnya bergantung pada import yang sebagian besar berasal dari Thailand. Padahal Indonesia memiliki jumlah bahan alam yang sangat banyak dan variatif yang mampu digunakan sebagai substrat untuk produksi FOS.

Beberapa mikroba penting dalam produksi FOS, baik bakteri maupun kapang (jamur) adalah Aspergillus sp., Aureobasidium sp., Arthrobacter sp., dan Fusarium sp. [5]. Kerja mikroba untuk produksi FOS adalah melalui produksi enzim fruktosiltransferase (FTases) yang bekerja pada media sukrosa [6]. A. niger AS 0023 dilaporkan mampu menghasilkan enzim FTase dan memproduksi sampai 54\% FOS dari bahan yang berkadar sukrosa 50\% [7]. Peneliti yang sama juga melaporkan produksi FOS dari Penicillium citrium sampai 55\% dengan penggunaan bahan yang mengandung $70 \%$ sukrosa.

Penggunaan mikroorganisme pada produksi FOS yang dilakukan sampai saat ini masih berfokus pada penggunaan beberapa bahan yang memiliki kandungan inulin sebagai sumber fruktosa, sementara penggunaan bahan pangan kaya karbohidrat belum dilakukan. Sulawesi Utara memiliki beberapa jenis bahan pangan khas kaya karbohidrat yang bisa digunakan sebagai media tumbuh mikroorganisme untuk produksi FOS. Sebagai contoh tanaman kelapa yang memiliki habitat yang cukup besar di Sulawesi Utara, yang masih mengandung bahan organik seperti karbohidrat yang mencapai 15,23 gram/100 gram, sementara air kelapa (tua dan muda) memiliki kandungan karbohidrat berupa sukrosa, glukosa dan fruktosa sejumlah 4,6 gram/100 gram. Kandungan makro dan mikro nutrient bahan limbah ini masih memungkinkan untuk proses fermentasi mikroba. Selain itu bahan pangan seperti pisang goroho (Musa acuminate), ubi jalar (Ipomoea batatas) dan gula merah yang merupakan bahan pangan asal sulawesi utara secara tradisional banyak digunakan karena memiliki nilai kesehatan. pisang goroho merupakan jenis pisang asal sulawesi utara, secara tradisional digunakan sebagai sumber karbohidrat bagi penderita diabetes mellitus (dm). penelitian menunjukkan bahwa pisang goroho memiliki indeks glikemik yang rendah [8], dimana kandungan karbohidratnya adalah non-digestible carbohydrate sehingga tidak akan mempengaruhi kandungan glukosa darah penderita $\mathrm{dm}$. untuk ubi jalar, selain kaya karbohidrat, merupakan bahan pangan kaya komponen penunjang kesehatan seperti $\beta$ carotene dan antosianin.

\section{Bahan dan Metode}

Alat yang digunakan adalah tabung reaksi, tabung sentrifus, cawan petri, Jarum Ose, Erlenmeyer, Batang pengaduk, Neraca analitik, $\mathrm{pH}$ meter dan pipet.

Penelitian ini dilaksanakan dengan metode studi literatur yang digabungkan dengan eksperimen uji tumbuh kapang Aspergillus niger dengan menggunakan Rancangan Acak Lengkap (RAL). Adapun perlakuannya adalah media tumbuh sejumlah 5 perlakuan, dengan melakukan 4 kali ulangan. Masing-masing media tumbuh adalah: 1) air kelapa; 2) ubi jalar; 3) campuran ubi jalar dan gula merah; 4) pisang goroho; 5) campuran pisang goroho dan ubi jalar.

\section{Mikroorganisme dan Kultur Medium}

Kultur murni kapang Aspergillus niger diperoleh dari hasil koleksi Laboratorium Bioteknologi Intitut Pertanian Bogor. Media untuk pemeliharaan kultur dengan menggunakan potato dextrose agar (PDA), dan untuk perbanyakan kapang digunakan Etanil, $\mathrm{HCl}$ pekat, $\mathrm{NaOH}, \mathrm{TCA}$, Aqua destilasi, 
Glukosa, Sukrosa, $\quad \mathrm{MgSO}_{4} .7 \mathrm{H}_{2} \mathrm{O}, \quad \mathrm{NaNO}_{3}$, $\mathrm{K}_{2} \mathrm{HPO}_{4}, \mathrm{KCl}$, Alkohol 70\%.

\section{Persiapan Media}

Perbanyakan kapang A. niger dilakukan pada cawan petri dengan media tumbuh PDA yang sebelumnya telah disterilisasi. Media air kelapa didapatkan dengan cara menampung air kelapa langsung dari buah kelapa; sementara untuk ubi jalar dan pisang goroho, masing-masing direbus sampai matang, kemudian dihaluskan dengan menggunakan blender. Untuk campuran gula merah, gula merah dilarutkan dengan perbandingan 1 buah gula merah dilarutkan pada $500 \mathrm{ml}$ air.

Prosedur pertumbuhan kapang Aspergillus niger dengan menggunakan 5 media tumbuh bahan pangan asal Sulawesi Utara terlihat pada Gambar 1.

Sejumlah 500 gram bahan kemudian ditambahkan dengan $200 \mathrm{ml}$ air (untuk ubi jalar dan pisang goroho) dan $200 \mathrm{ml}$ larutan gula merah (untuk campuran ubi jalar + gula merah dan pisang goroho + gula merah). Untuk mensterilkan media, dimasukkan ke dalam autoclave pada suhu $121^{\circ} \mathrm{C}$ selama 1 jam. Selanjutnya masing-masing media diletakkan pada wadah plastik berukuran $30 \times 25 \mathrm{~cm}$ dengan ketebalan $3 \mathrm{~cm}$. Uji tumbuh dilakukan dengan melarutkan koloni $A$. niger yang telah diperbanyak pada petry dish dengan $50 \mathrm{ml}$ air dan kemudian disiramkan di atas media uji secara merata. Untuk menghindari kontaminasi, setelah koloni disiramkan, wadah kemudian ditutup dengan plastik dan kemudian dilubangi kecil-kecil untuk membiarkan udara masuk. Hal ini dilakukan karena fermentasi kapang $A$. niger terjadi pada keadaan aerob.

\section{Perhitungan Uji Tumbuh}

Pengamatan hasil uji tumbuh dilakukan dengan menghitung luasan area penutupan kapang A. niger pada media tumbuh, dengan menggunakan nilai persentasi tumbuh. Nilai persentasi tumbuh dihitung dari luasan tutupan sebaran koloni kapang $A$. niger dari $0-100 \%$.

\section{Hasil dan Pembahasan}

Perkembangan Pangan Fungsional

Pangan fungsional pertama kali diperkenalkan di Jepang sekitar tahun 1980-an, dimana munculnya Peraturan Pemerintah tentang proses pangan fungsional yang disebut sebagai Foods for Specific Health Use (FOSHU = pangan yang digunakan khusus untuk kesehatan), yang merujuk pada pangan yang diproses secara khusus dan memiliki komposisi fungsional sebagai tambahan zat gizi. Perkembangan di Jepang ini membuka ketertarikan ilmuwan di belahan dunia lainnya tentang pangan fungsional. Sekalipun demikian, ada perbedaan pemahaman konsep negara-negara Eropa dan Amerika yang lebih mempertimbangkan kealamian dari pangan fungsional di banding Jepang [2]. Contohnya, di Jepang, ketika suatu produk telah disetujui maka akan ditempeli "FOSHU" dan langsung dipajang di toko-toko, dalam hal ini fungsi lebih tinggi dibanding rasa. Sebaliknya di Eropa dan Amerika pertanyaan konsumen akan lebih mengarah pada konsep, dimana pangan fungsional diartikan sebagai suatu upaya menambahkan sesuatu yang berfungsi baik pada produk makanan tradisional dan produk tersebut tidak menciptakan kelompok berbeda dengan makanan tradisional yang telah lama dikenal sebelumnya [9].

Pada Konferensi Internasional ke 9 tentang "Pangan Fungsional dan Penyakit Kronis: Ilmu dan Penerapannya" di Universitas Nevada, Amerika pada 15 - 17 Maret, 2011, dilakukan perumusan definisi Pangan Fungsional baru menjadi: "Pangan Fungsional adalah bahan alam atau bahan makanan yang telah diproses yang diketahui mengandung senyawa biologi aktif dimana secara kualitas dan kuantitatif dalam jumlah tertentu yang dibuktikan secara klinis dan tertulis mampu memberikan keuntungan bagi kesehatan sehingga merupakan sumber penting dalam pencegahan dan pengobatan penyakit kronik di era modern". pangan fungsional diartikan sebagai pangan makanan yang mengalami penambahan bahan-bahan baru dimana bahanbahan tambahan tersebut memiliki tambahan fungsi baru yang biasanya dikaitkan dengan kesehatan atau pencegahan penyakit. Dalam pengertian ini, pangan fungsional adalah bagian dari pangan sehari-hari yang memiliki 
komponen biologi aktif yang berguna untuk meningkatkan kesehatan dan mengurangi resiko penyakit, sehingga tidak dibenarkan untuk menambahkan sutu senyawa aditif ataupun bahan obat-obatan dan mengklaimnya sebagai pangan fungsional $[9,10]$.

Produk pangan fungsional yang berkembang saat ini umumnya adalah produk susu, sereal dan biskuit, minuman ringan dan permen. Untuk susu yang dimodifikasi terutama adalah produk untuk tulang, misalnya susu yang diperkaya dengan penambahan kalsium, misalnya yang diproduksi di Spanyol, Amerika, Perancis, dan Australia, dimana kurangnya sinar matahari menyebabkan penyerapan kalsium tulang menjadi rendah. Selain itu produk yang dikembangkan untuk usus, misalnya yoghurt probiotik dan minuman, juga produk simbiotik antara probiotik dan prebiotik yang dikembangkan di Eropa [2]. Untuk produk bagi kesehatan hati, misalnya adalah produk untuk mengurangi kolesterol dengan ester stanol tanaman (contoh produknya adalah Benecol), penurun tekanan darah dan susu fermentasi misalnya.

Konsep Probiotik dan Prebiotik Sebagai Pangan Fungsional

Dengan mempertimbangkan pangan fungsional sebagai pangan yang mampu memberikan fungsi selain pengenyang, konsep probiotik dan prebiotik semakin menjadi fokus penelitian saat ini. Konsep pangan fungsional adalah dengan menggabungkan probiotik dan prebiotic yang lebih mengarah pada pangan aditif yang mampu memberikan efek positif pada keseimbangan mikroba usus halus [11]. Probiotik adalah suplemen makanan mikroba hidup dimana yang paling sering digunakan adalah bakteri asam laktat dan bifido, yang banyak digunakan dalam yoghurt dan produk susu lainnya [2]. Sebaliknya prebiotik adalah bahan makanan yang tidak dicerna dalam lambung yang selektif merangsang pertumbuhan atau kegiatan, atau keduanya, laktobasilus atau bifidobacteria dalam usus besar, dengan demikian meningkatkan kesehatan [11]. Probiotik dan prebiotik dalam diet dapat memodifikasi komposisi dan beberapa kegiatan metabolisme mikroflora.
Pengamatan tentang efek probiotik sudah sejak lama dilakukan, bahkan sebelum konsep probiotik didefinisikan. Misalnya produksi yoghurt yang sudah dilakukan berabad lampau yang justru nanti disadari setelah melihat adanya efek positif pada peminum yoghurt di daerah Eropa Timur. Efek positif inilah yang memacu pemahaman tentang adanya pengaruh dari bahan pangan yang sudah difermentasi terhadap terhadap kesehatan manusia. Di Indonesia, beberapa pangan hasil fermentasi, seperti tahu, tempe, tape, kecap (di Jawa) serta bakasang (di Sulawesi Utara) merupakan salah satu kebijakan lokal tentang pangan fungsional yang telah berkembang sejak berabad yang lalu yang memerlukan penelitian lanjutan untuk mengembangkan pangan fungsional tradisional.

Fruktooligosakarida (FOS)

Fruktooligosakarida (FOS) adalah polimer alami fruktosa (contohnya oligofruktosa dan inulin) yang tahan terhadap hidrolisis enzim-enzim pencernaan dalam lambung, tetapi sangat mudah terfermentasi dalam usus halus dan kolon menjadi asam lemak rantai pendek dan laktat [12]. Secara spesifik FOS merujuk pada unit D-fruktosa rantai pendek yang terikat pada unit $\beta-1,2$, Dglukosa atau sukrosa [4, 13].

Umumnya FOS digunakan untuk meningkatkan rasa manis makanan, dan dikonsumsi dalam bentuk roti, makanan kecil, dan produk dari susu [14]. Selain penting dalam industri pangan, FOS merupakan gula yang tidak berkalori yang sangat sulit dihidrolisi enzim lambung dan tidak bisa digunakan sebagai energi tubuh sehingga aman bagi penderita diabetes. Keuntungan lain dari FOS adalah tidak membentuk karang gigi karena tidak bisa dihidrolisi oleh bakteri pembentuk asam pada gigi. Ini menjadi penting, terutama untuk produksi permen yang biasa diminati anak kecil, dengan menggunakan FOS akan dihasilkan permen yang tidak mengakibatkan kerusakan gigi. Dalam metabolisme pada hewan, FOS akan meningkatkan pertumbuhan bifidobakteri dan mencegah pertumbuhan mikroba patogen pada usus [4]. Dalam hubungannya dengan metabolisme lemak, FOS diketahui mampu menurunkan kolesterol, 
fosfolipid dan trigliserida dalam darah, karena FOS yang dicerna mikroba akan membentuk asam lemak rantai pendek (asetat, butirat dan propionat), sehingga lebih mudah untuk dioksidasi menjadi energi dibanding glukosa [12].

Tabel 1. Konsentrasi FOS pada beberapa bahan makanan [6].

\begin{tabular}{|l|c|}
\hline \multicolumn{1}{|c|}{ Bahan Pangan } & Jumlah FOS (\%) \\
\hline Gandum & 0,15 \\
Tomat & 0,15 \\
Bawang Merah & 0,23 \\
Pisang & 0,30 \\
Gula merah & 0,30 \\
Bawang Putih & 0,60 \\
Madu & 0,75 \\
\hline
\end{tabular}

Penelitian Chien dalam Maiorano melaporkan penggunaan Aspergillus japonicas pada larutan $100 \mathrm{ml}$ sukrosa yang mampu menghasilkan $61 \%$ FOS dari total gula yang terbentuk [5]. Yun menjelaskan mekanisme kerjanya, dimana FTase merubah sukrosa menjadi 1-kestose kemudian menjadi 1-nistose diikuti oleh 1-fruktofuranosylnitose [4]. Sangeetha melaporkan produksi FOS sampai 58\% dari Aspergillus oryzae CFR 202, sementara A. pullulans CFR 77 mampu memproduksi sampai $60 \%$ FOS [6]. Selanjutnya Prapulla juga melaporkan beberapa mikroba yang mampu memproduksi FOS dari sukrosa, masingmasing Aspergillus phoenicis, A.japonicus, A.niger, Fusarium oxysporum, Scopulariopsis, brevicaulis, Penicillium frequentens, Penicilliumrugulosum, Aereobasidium pullulans dan Arthrobacter sp. Penelitian dari Dominguez, dalam Maiorano menghasilkan metode sederhana dalam mengukur produksi glukosa dan fruktosa pada proses fermentasi [5]. Metode ini memungkinkan mengukur aktifitas kapang berdasarkan jumlah perbanyakannya dan juga bisa melihat aktifitas aktifitas transfruktosilasi dari spesies kapang yang berbeda.

Ada 2 metode dalam memproduksi enzim fruktosiltransferase, masing-masing melalui mekanisme fermentasi submerged ( $\mathrm{SmF}=$ submerged fermentation) dan mekanisme fermentasi keadaan padat (SSF $=$ solid state fermentation). Sangeetha selanjutnya melaporkan bahwa produksi yang optimum dan berbiaya rendah didapatkan dari mekanisme SSF, sementara untuk SSF sangat baik untuk digunakan pada substrat yang berasal dari limbah pengolahan bahan pangan [6].

Beberapa penelitian pada media/substrat limbah, antaranya by product jagung, limbah tapioca, limbah pengolahan tebu yang dilakukan menunjukkan hasil yang positif dengan menggunakan kapang Aspergillus niger dan A. oryzae [6].

\section{Kapang Aspergillus niger}

Aspergillus niger adalah kapang yang paling sering digunakan dalam industri pangan. Seperti jenis kapang lainnya, pembentukan spora $A$. niger akan menghasilkan debu berwarna hitam (Gambar 2) yang akan bermasalah jika sampai masuk dalam saluran pencernaan, tetapi jika dibandingkan

dengan spesies lain, belum dikategorikan berbahaya [15]. A.niger merupakan organisme eukariotik dari genus Aspergillus, menjadi salah satu mikroorganisme penting yang digunakan dalam bioteknologi. A. niger terutama digunakan untuk memproduksi beberapa enzim, misalnya produksi asam sitrat (E330) dan asam glukonik (E574) dan untuk produksi enzim ekstraseluler yang berguna bagi pengolahan pangan dan juga digunakan pada pembuatan protein seperti protein sitokin interleukin manusia [15]. Aspergillus niger juga menjadi kapang yang mampu menghasilkan enzim lipase, suatu enzim yang mampu menghidrolisis trigliserida menjadi asam lemak dan gliserol, sehingga membantu industri pangan dalam memproduksi pangan berenergi rendah dan juga untuk produksi obat [16].

Produksi fruktooligosakarida kapang Aspergillus niger saat ini menjadi sumber utama dalam industri. Hal ini karena produksi enzim A. niger sangat efisien dalam memproduksi enzim pengurai sukrosa [17]. Pengembangan kapang A.niger untuk produksi FOS dilakukan dengan fermentasi bahan sumber sukrosa yang dilakukan oleh kerja enzim glukosa oksidase. Penelitian sebelumnya menunjukkan bahwa sukrosa yang difermentasi dengan kapang $A$. niger akan menghasilkan FOS sampai $70 \%$. Sementara L'Hocine melaporkan produksi intraselluler enzim fruktosiltransferase mampu 
meningkatkan 54\% FOS pada bahan yang mengandung $50 \%$ sukrosa [7].

Uji Pertumbuhan Kapang Aspergillus niger Pada Beberapa bahan Pangan

Kapang A. niger yang ditumbuhkan pada medium pertumbuhan, dimana karbohidrat dari masing-masing bahan pangan tersebut menjadi sumber makanan kapang. A. niger merupakan kapang dengan ciri warna hitam. Berdasarkan hasil pengamatan untuk uji tumbuh, pertumbuhannya pada media yang digunakan terlihat merata pada 4 media yang ada (Gambar 3), tetapi tidak pada media ubi jalar yang dicampur dengan gula merah. Koloni dari kapang $A$. niger pada media ubi jalar yang dicampur gula merah terlihat tertutup oleh kapang lain yang menimbulkan bau busuk menyengat.

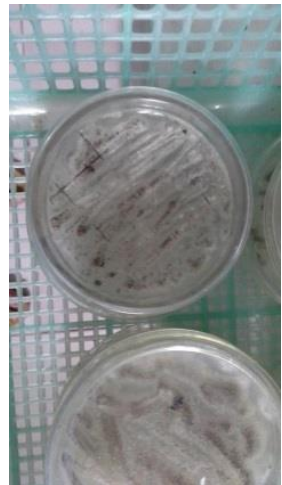

Gambar 2. Koloni A.niger

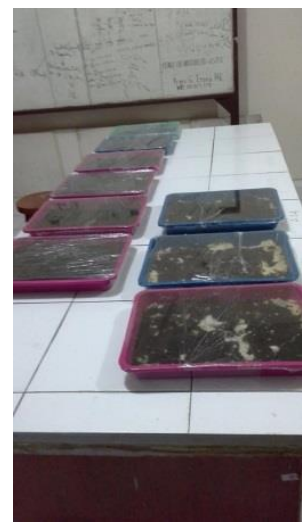

Gambar 3. Pertumbuhan kapang pada beberapa media

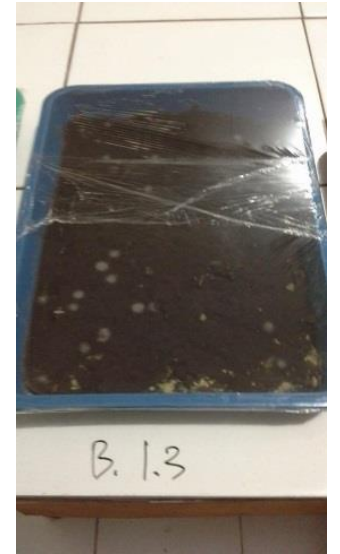

Gambar 4. Pertumbuhan kapang pada media pisang

Pada media dimana terjadi pertumbuhan $A$. niger (Gambar 4), tercium bau harum alkohol yang membuktikan adanya aktifitas fermentasi sempurna dari kapang tersebut. Dari penampakan media, keseluruhan permukaan media diselimuti koloni $A$. niger secara merata.

Berdasarkan sifat tumbuhnya pada bahan pangan, kapang akan menunjukkan aktifitas berbeda pada substrat yang berbeda. Media tumbuh yang mampu menyiapkan nutrisi yang dibutuhkan untuk pertumbuhan kapang menjadi media yang akan menghasilkan koloni terbanyak.

Berdasarkan hasil analisa keragaman uji pertumbuhan kapang Aspergillus niger pada 5 media yang dilakukan menunjukkan adanya perbedaan yang sangat nyata antara tiap media dengan nilai $\mathrm{F}$ hitung mencapai 680.4 pada $\mathrm{F}$ tabel $3.26(0.05)$ dan 5.41 (0.01). Sebaran koloni terbanyak dicapai pada media pisang goroho yang mencapai 100\%. Sementara untuk campuran ubi jalar dengan gula merah sebaran koloninya sangat kecil karena dikuasai oleh koloni mikroorganisme yang tidak bisa diidentifikasi.

Melalui uji perbandingan harga ratarata dengan BNT (Beda Nyata Terkecil) pada tingkat $\mathrm{F}$ tabel 0.05 dan 0.01 terhadap masingmasing media diperoleh hasil media campuran ubi jalar dan gula merah menunjukkan perbedaan sangat nyata terendah dibanding media lainnya. Selanjutnya perbedaan juga terjadi antara masing-masing media, kecuali antara media pisang goroho dan media campuran pisang goroho dan gula merah yang tidak berbeda nyata. Perbedaan ini sejalan 
dengan sifat dari mikroorganisme yang cenderung akan tumbuh pada media yang mampu menyiapkan nutrisi yang sesuai dengan kebutuhannya untuk tumbuh. Pada air kelapa, sekalipun masih tersedia nutrisi yang baik, tetapi pertumbuhan kapang $A$. niger terhambat oleh sifat media yang cair. Sementara untuk media campuran ubi jalar dan gula merah, terhambatnya pertumbuhan kapang $A$. niger mungkin disebabkan oleh kandungan sukrosa yang terlalu tinggi. Meningkatnya sukrosa yang berasal dari gula merah menyebabkan laju pertumbuhan kapang A. niger menjadi sedikit terhambat karena ubi jalar juga mampu menyiapkan sumber pati yang melimbah. Untuk pisang goroho, belum ada hasil analisa kandungan karbohidratnya, tetapi secara tradisional suku Minahasa menggunakan jenis pisang ini sebagai makanan untuk penderita diabetes mellitus karena indeks glikemik dari pisang ini rendah. Indeks glikemik yang rendah dapat menunjukkan pisang goroho memiliki karbohidrat yang sulit dicerna (non digestible carbohydrate) yang tinggi sehingga menjadi media yang baik untuk kerja mikroorganisme. Penambahan gula merah sebagai sumber sukrosa mampu menyiapkan kondisi yang optimal bagi kapang ini untuk tumbuh.

\section{Kesimpulan}

Berdasarkan studi literatur Aspergillus niger diketahui memiliki kemampuan tinggi dalam melakukan fermentasi di berbagai media. Hal ini memungkinkan penggunaan Aspergillus niger dalam fermentasi beberapa bahan pangan local Sulawesi Utara. Selanjutnya uji tumbuh yang dilakukan pada beberapa media, masing-masing air kelapa, ubi jalar dan pisang goroho menunjukkan adanya perbedaan sangat nyata pertumbuhan dari masing-masing media.

Mengingat semakin tingginya permintaan pangan fungsional, maka potensi untuk memproduksi FOS dari bahan pangan asal Sulawesi Utara dengan bantuan kapang Aspergillus niger terbuka dikembangkan di Sulawesi Utara. Dibutuhkan penelitian lanjutan untuk menguji konsentrasi fruktooligosakarida yang diproduksi oleh fermentasi tersebut.

\section{Daftar Pustaka}

1. Menrad, K., Market and marketing of functional food in Europe. Journal of food engineering 2003, 56, (2-3), 181-188.

2. Clydesdale, F. M., A proposal for the establishment of scientific criteria for health claims for functional foods. Nutrition reviews 1997, 55, (12), 413-422.

3. Flamm, G.; Walter Glinsmann; David Kritchevsky; Leon Prosky; Roberfroid, M., Inulin and oligofructose as dietary fiber: a review of the evidence. Critical reviews in food science and nutrition 2001, 41, (5), 353362.

4. Yun, J. W., Fructooligosaccharidesoccurrence, preparation, and application. Enzyme and microbial technology 1996, 19, (2), 107-117.

5. Maiorano, A. E.; Piccoli, R. M.; Da Silva, E. S.; de Andrade Rodrigues, M. F., Microbial production of fructosyltransferases for synthesis of pre-biotics. Biotechnology letters 2008, 30, (11), 1867.

6. Sangeetha, P.; Ramesh, M.; Prapulla, S., Recent trends in the microbial production, analysis and application of fructooligosaccharides. Trends in food science E technology 2005, 16, (10), 442-457.

7. L'Hocine, L.; Zhang Wang; Bo Jiang; Xu, S., Purification and partial characterization of fructosyltransferase and invertase from Aspergillus niger AS0023. Journal of biotechnology 2000, 81, (1), 73-84.

8. Suryanto, E.; Lidya Irma Momuat; Mercy Taroreh; Wehantouw, F., Potensi senyawa polifenol antioksidan dari pisang goroho (Musa sapien Sp.). Agritech 2011, 31, (4).

9. Siro, I.; Kápolna, E.; Kápolna, B.; Lugasi, A., Functional food. Product development, marketing and consumer acceptance-A review. Appetite 2008, 51, (3), 456-467.

10. Roberfroid, M. B., Concepts and strategy of functional food science: the European perspective-. The American journal of clinical nutrition 2000, 71, (6), 1660S-1664S.

11. Ziemer, C. J.; Gibson, G. R., An overview of probiotics, prebiotics and synbiotics in the functional food concept: perspectives and future strategies. International Dairy Journal 1998, 8, (5-6), 473-479. 
12. Delzenne, N. M.; Kok, N.; Fiordaliso, M.-F.; Deboyser, D. M.; Goethals, F. M.; Roberfroid, M. B., Dietary fructooligosaccharides modify lipid metabolism in rats. The American Journal of Clinical Nutrition 1993, 57, (5), 820S-820S.

13. Swanson, K. S.; Grieshop, C. M.; Flickinger, E. A.; Bauer, L. L.; Healy, H.-P.; Dawson, K. A.; Merchen, N. R.; Fahey Jr, G. C., Supplemental fructooligosaccharides and mannanoligosaccharides influence immune function, ileal and total tract nutrient digestibilities, microbial populations and concentrations of protein catabolites in the large bowel of dogs. The Journal of nutrition 2002, 132, (5), 980-989.

14. Molis, C.; Flourie, B.; Ouarne, F.; Gailing, M.-F.; Lartigue, S.; Guibert, A.; Bornet, F.; Galmiche, J., Digestion, excretion, and energy value of fructooligosaccharides in healthy humans. The American journal of clinical nutrition 1996, 64, (3), 324-328.

15. Schuster, E.; Dunn-Coleman, N.; Frisvad, J.; Van Dijck, P., On the safety of Aspergillus niger-a review. Applied microbiology and biotechnology 2002, 59, (45), 426-435.

16. Falony, G.; Armas, J. C.; Mendoza, J. C. D.; Hernández, J. L. M., Production of Extracellular Lipase from Aspergillus niger by Solid-State Fermentation. Food Technology \& Biotechnology 2006, 44, (2).

17. Hidaka, H.; Masao Hirayama; Sumi., N., A fructooligosaccharide-producing enzyme from Aspergillus niger ATCC 20611. Agricultural and Biological Chemistry 1988, 52, (5), 1181-1187. 